\title{
Pemberdayaan masyarakat Pada Usaha Mikro Kecil Menengah Anugerah Foods Sentra Aneka Keripik di Desa Jungke Magetan
}

\author{
Dian Citaningtyas Ari Kadi, ${ }^{1}$ Rizal Ula Ananta Fauzi ${ }^{2}$ \\ 1,2 Prodi Manajemen, Fakultas Ekonomi dan Bisnis Universitas PGRI Madiun , Indonesia \\ M Email : Citakirana11@gmail.com
}

\begin{tabular}{l|l|l} 
Received : 16-01-2021 | Revised : 16-03-2021 | Accepted : 17-04-2021
\end{tabular}

\begin{abstract}
Community service programs are programs that aim to help the community without expecting anything in return. This service program seeks to help the Micro, Small, and Medium Enterprises (MSME) group "Anugerah Foods, Various Chips Center" located in Jungke Village, Karas District, Magetan Regency in dealing with various problems. Anugerah Foods is currently still constrained by a marketing strategy that still uses a personal selling strategy or is sold around Jungke Village. The main objective of this community service program is to provide innovation by introducing an online marketing system. The innovation introduced to Anugerah Foods is an online marketing strategy through a website, namely WordPress and social media in the form of Facebook and Instagram. By conducting visits and training on online strategy operations to Anugerah Foods members, it is our effort to convey innovation to be able to compete in the market and maintain good product quality. For students, this community service program is intended to fulfill entrepreneurial learning tasks and learn about entrepreneurship that they upload.
\end{abstract}

Keywords: Online marketing, Inovation, MSME, Chips Center

\section{Pendahuluan}

Usaha Mikro Kecil dan Menengah (UMKM) merupakan bisnis yang memiliki peranan sangat penting dalam perekonomian khususnya di Inonesia baik dari sisi jumlah lapangan pekerjaan maupun dari sisi bisnis yang diciptakan (Rudjito 2003). Secara spesifik adanya UMKM juga dipercaya dapat berkontribusi terhadap upaya pengentasan kemiskinan melalui penciptaan lapangan kerja bagi mayoritas masyarakat Indonesia. UMKM memiliki peran penting sebagai sarana untuk mengangkat masyarakat kecil keluar dari kemiskinan. Menurut Badan Pusat Statistik (BPS), jumlah usaha mikro, kecil, dan menengah (UMKM) mencapai 64 juta. Angka ini telah mencapai 99,9\% dari seluruh bisnis di Indonesia. (Liputan6.com). Keberadaan UMKM sudah tidak diragukan lagi, karena fakta membuktikan bahwa mereka mampu bertahan dan menjadi motor penggerak perekonomian, terutama pasca krisis ekonomi selain itu modal masih menjadi kendala bagi wirausaha dalam menjalankan usahanya(Fauzi ,2021). Sehingga untuk efisiensi biaya bisa menggunakan sisitem penjualan online.

- Namun, kurangnya informasi, terutama perolehan informasi pasar, menjadi kendala karena terbatasnya pemahaman dan penggunaan teknologi serta akses informasi 
pasar yang terbatas sehingga mengarah pada orientasi pasar yang rendah dan daya saing yang lemah. Oleh karena itu, pelaku UMKM harus terus berinovasi untuk meningkatkan usahanya agar dapat bertahan dalam jangka panjang baik dari segi pengemasan, promosi maupun penjualan. Menurut Fauzi et al. (2020) Inovasi mampu memberikan nilai positif bagi pelaku UMKM.

Dari hal tersebut, maka kami melakukan program pengabdian masyarakat di sentra industri aneka keripik di Desa Jungke, Kecamatan Karas, Kabupaten Magetan berdiri sejak tahun 2017. Usaha ini dinaungi oleh beberapa pengurus di Desa Jungke dengan nama "Anugerah Foods". Usaha ini bersifat home industry. Keripik yang diproduksi di sentra ini diantaranya adalah keripik pare, keripik sukun, dan kacang dimana keripik ini merupakan makanan ringan yang banyak diminati oleh kalangan masyarakat khususnya di Desa Jungke. Selain bisa dijadikan camilan, keripik ini juga bisa dijadikan lauk karena keripik ini berbeda dari keripik biasanya khususnya keripik pare yang memiliki rasa gurih dan tidak pahit.

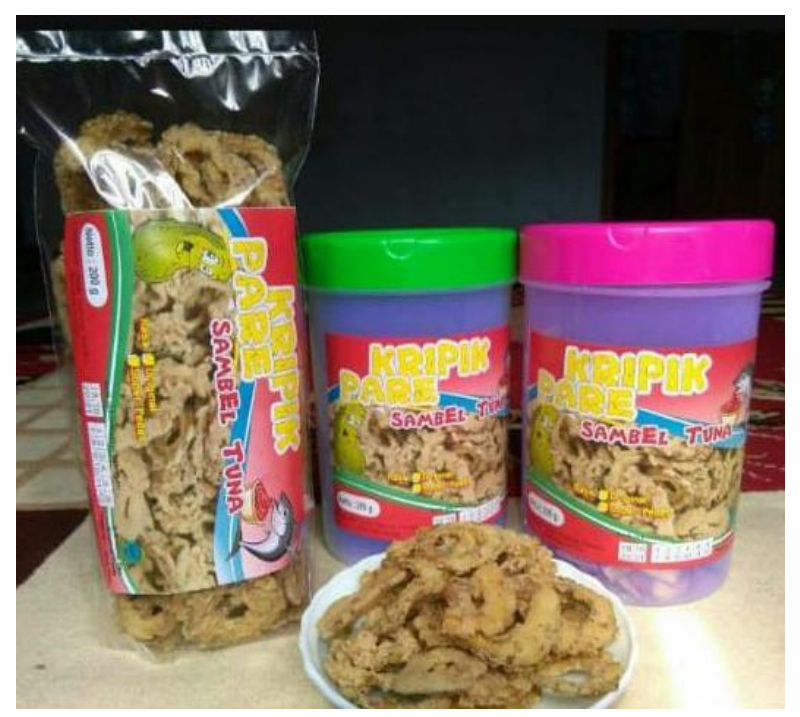

Gambar 1. Contoh Produk

Berdasarkan hasil kunjungan dan pengamatan kelompok kami secara langsung di Desa Jungke, kendala yang dialami oleh Anugerah Foods adalah keterbatasan pengetahuan pasar dan teknologi untuk meningkatkan skala ekonomi usahanya, yaitu dari segi pemasaran. Kadi et al ( 2020) bahwa EWOM menyebarkan informasi melalui media online atau Internet, seperti email, blog, ruang obrolan, Facebook, Twitter. Bisa dilihat dalam gambar 1 yatu contoh produk sebelum diinovasi, fotonya kurang menarik apabila akan di unggah dimedia sosial. Memang dalam memasarkan produk Anugerah Foods masih menggunakan cara tradisional yakni personal selling atau hanya dijual di pasaran Desa Jungke dan sekitarnya. Akibatnya usaha ini belum dikenal oleh masyarakat luas karena terbatasnya sarana dan kurangnya kemampuan dalam memasarkan produk tersebut. Kami juga mencoba membuat foto produk yang lebih menarik agar bisa bersaing di media sosial. Bisa dilihat pada gambar 2 yakni foto produk setelah diinovasi. Hasil fotonya lebih menarik dan lebih fresh dengan konsep yang baru namun dengan produk yang sama. 


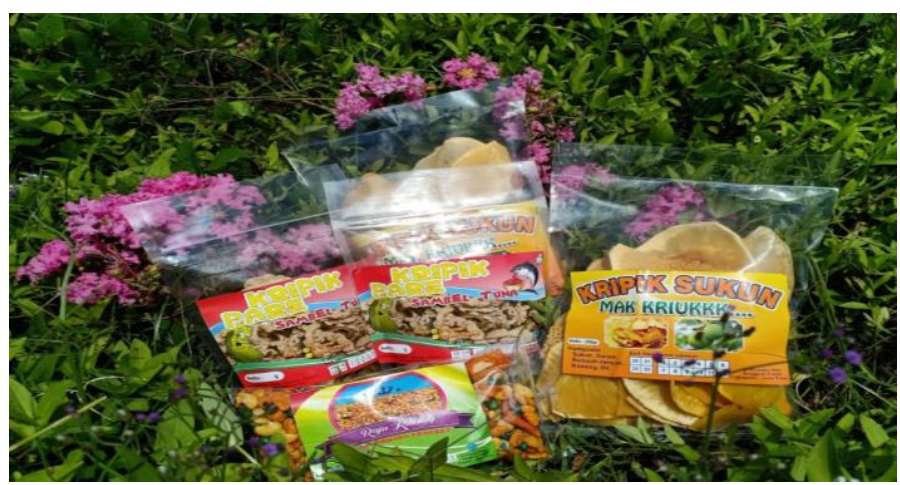

Gambar 2. Produk

Dengan ini, kami membantu untuk memberikan sebuah inovasi dalam memperbaiki strategi pemasaran produk Anugerah Foods dengan membuat website yaitu WordPress dan akun penjualan di media sosial diantaranya Instagram dan Facebook. [rizal et al .2021)] Digital Marketingmerupakan suatu proses perencanaan dan pelaksanaan dari konsep, ide, harga, promosi dan distribusi. Arman et al. (2020) dalam pemasaran online mepunyai banyak keuntungaan Inovasi ini bertujuan agar keripik yang diproduksi Anugerah Foods dapat dikenal oleh masyarakat luas sehingga dapat meningkatkan penjualan dan keuntungannya.karena inovasi mampu meninggkatkan nilai value suatu barang( Fauzi ,2020)

\section{Metode}

Program pengabdian masyarakat dilakukan selama 5 minggu pada bulan November 2020. Program ini dilakukan di Sentra UMKM pembuatan makanan ringan "Anugerah Foods" yang bertempat di Desa Jungke, Kecamatan Karas, Kabupaten Magetan. Tahapan yang dilakukan pada program kali ini yaitu:

Tabel 1

Tahapan program pengabdian masyarakat

\begin{tabular}{|c|l|c|c|c|c|c|}
\hline \multirow{2}{*}{ N } & \multicolumn{1}{|c|}{ Nama Kegiatan } & \multicolumn{5}{|c|}{ Minggu Ke- } \\
\cline { 3 - 7 } & & I & II & III & IV & V \\
\hline 1. & Survey UMKM & & & & & \\
\hline 2. & Analisis Permasalahan & & & & & \\
\hline 3. & Perencanaan Ide dan Inovasi & & & & & \\
\hline 4. & Pengembangan Ide dan Inovasi & & & & & \\
\hline 5. & Laporan Pengabdian & & & & & \\
\hline
\end{tabular}

1. Tahap Survey

Pada tahap survey UMKM kelompok kami melakukan survey pada usaha yang membutuhkan ide dan inovasi dalam segi pemasaran. Dari beberapa UMKM yang kami survey, kami memilih sentra industri aneka keripik Anugerah Foods untuk dijadikan pilihan dalam program pengabdian masyarakat ini.

2. Tahap Analisis Permasalahan 
Setelah menemukan tempat yang cocok untuk menjalankan program pengabdian masyarakat, kami berusaha menganalisis pokok permasalahan dari segi pemasaran pada sentra industri Anugerah Foods.

3. Tahap Perencanaan

Setelah ditemukan pokok permasalahan yang ada, kami berusaha memberi ide dan inovasi yang terbaik terkait tentang pemasaran aneka keripik yang dijual. Pada tahap ini, kami mempersiapkan data-data yang harus dilengkapi dalam pembuatan website dana kun media sosial.

4. Tahap Pengembangan

Pada tahap pengembangan ini kami melakukan inovasi dalam pembuatan situs website WordPress dan akun media sosial berupa Instagram dan Facebook.

5. Tahap Pembuatan Laporan

Tahap pembuatan laporan merupakan tahapan akhir yang harus kita jalani dari serangkaian tahapan yang sudah dikerjakan.

\section{Hasil dan Pembahasan}

Program pengabdian masyarakat kali ini menghasilkan pengembangan produk melalui strategi pemasaran produk makanan ringan Anugerah Foods yang dilaksanakan pada tanggal 01 Nopember - 31 Nopember 2020. Program pendampingan UMKM ini berjalan dengan lancar dengan dihadiri oleh 11 mahasiswa dan 2 orang wakil dari UMKM.

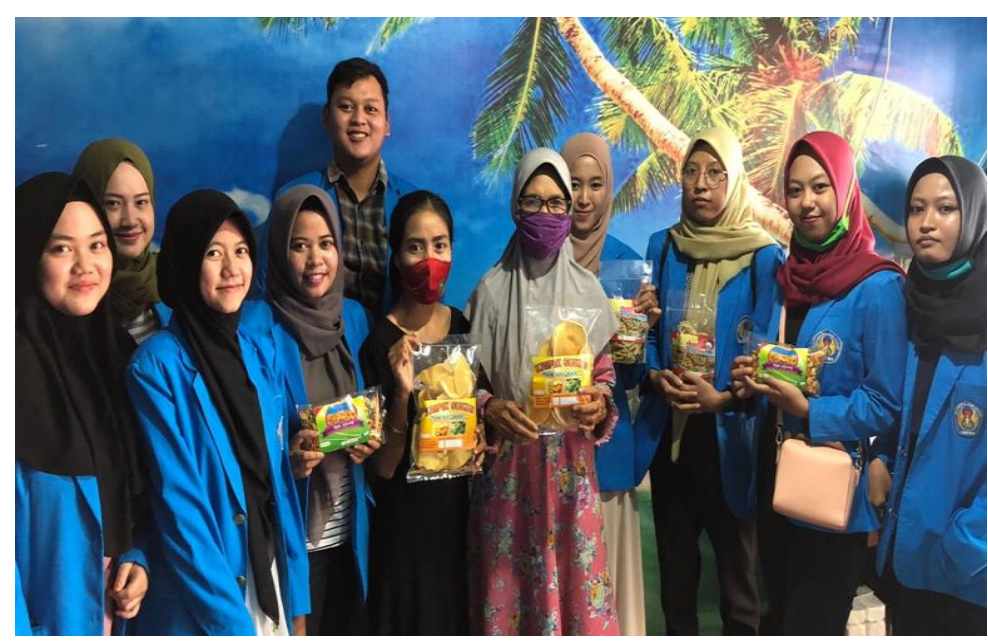

Gambar 3. Anggota Mahasiswa dan Wakil UMKM

Materi yang disampaikan mengenai konsep pengembangan produk, arti penting pemasaran, peningkatan kualitas maupun kuantitas produk serta mengidentifikasi permasalahan yang layak diangkat untuk menjadi jurnal diberikan pada pertemuan pertama. Pada pertemuan kedua peserta program pengabdian masyarakat melakukan pembuatan konsep strategi pemasaran online yang akan digunakan bersama-sama dengan wakil dari UMKM tersebut, sebagian besar ide yang dipakai tergantung permintaan dari UMKM, sedangkan mahasiswa membantu dalam proses pembuatan akun website dan media sosial. Berdasarkan hasil dari program ini dapat diidentifikasi mengenai tingkat 
pemahaman peserta program pengabdian adalah bahwa UMKM memahami konsep pengembangan produk, arti penting strategi pemasaran dan arti penting peningkatan kualitas dan kuantitas produk.

Dari program pengabdian masyarakat yang telah dilakukan diharapkan mampu meningkatkan jumlah produksi dan penjualan "Keripik Sukun, Keripik Pare dan Kacang Anugerah Foods", serta memperluas segmen pasar kepada masyarakat luas tidak hanya di wilayah Magetan saja. Beberapa kegiatan dilakukan yaitu dengan melakukan suatu inovasi baru atau ide yang kreatif guna menciptakan dan mendukung kemajuan atas produksi keripik sukun, keripik pare dan kacang Anugerah Foods.

Produk keripik sukun, keripik pare dan kacang Anugerah Foods yang semula tidak mempunyai website dilakukan pembuatan website yang bertujuan untuk menampilkan katalog produk atau portofolio dari produk yang sudah dijalankan selama ini, sehingga produk bisa diketahui oleh konsumen secara online.

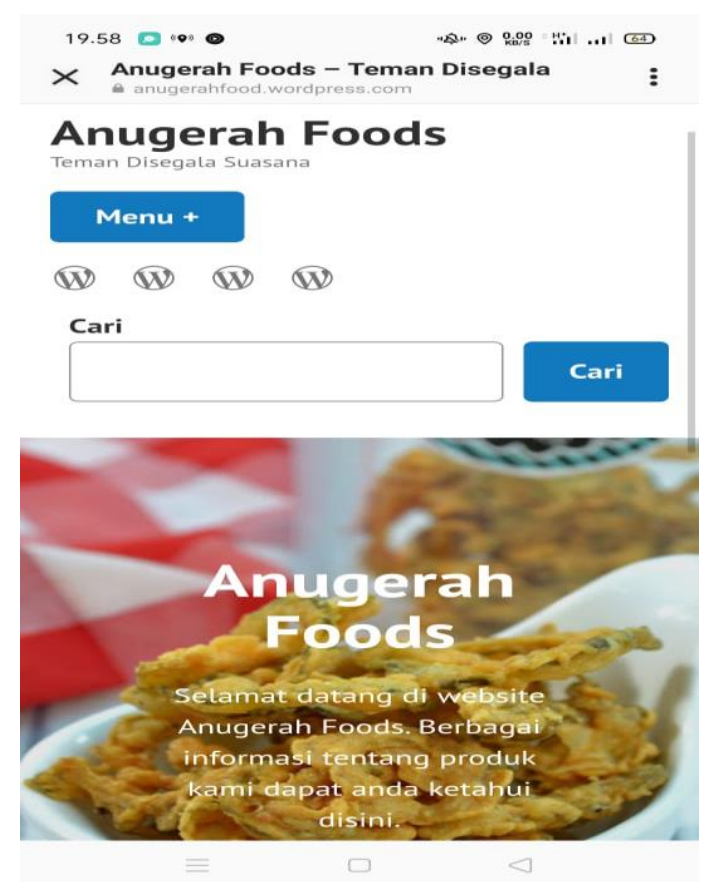

Gambar 4. Hasil Inovasi WordPress

Dengan adanya website dapat berguna sebagai sarana promosi yang dapat menciptakan engagement ke konsumen. Website akan meningkatkan kredibilitas produk. Dengan eksitensi produk di internet, kredibilitas usaha atau bisnis juga akan meningkat. Konsumen akan menilai bahwa produk tersebut memang benar-benar ada dan disini juga konsumen akan menilai keseriusan dalam menjalankan usaha. Adapun alamat website yang dapat di akses oleh konsumen https://anugerahfood.WordPress.com/. Dengan adanya website ini konsumen tetap dengan nyaman melihat produk ketika toko tutup. Sehingga kemungkinan untuk menjaring lebih banyak calon konsumen akan semakin besar.

Selanjutnya program pengabdian masyarakat kami mencoba melakukan pengembangan dengan membuatkan akun Instagram dan Facebook guna mendukung website yang sudah ada. Dengan membuatkan akun Instagram untuk produk keripik pare, 
keripik sukun dan kacang Anugerah Foods guna meningkatkan dan menambah jumlah produksi produk. Instagram sangat digemari karena memiliki banyak pengguna. Pada tahun 2020, sebagian besar pengguna ini menghabiskan rata-rata 28 menit sehari untuk menjelajahi aplikasi ini. Sehingga tidak menutup kemungkinan mayoritas pengguna Instagram mengikuti akun Anugerah Foods di Instagram.

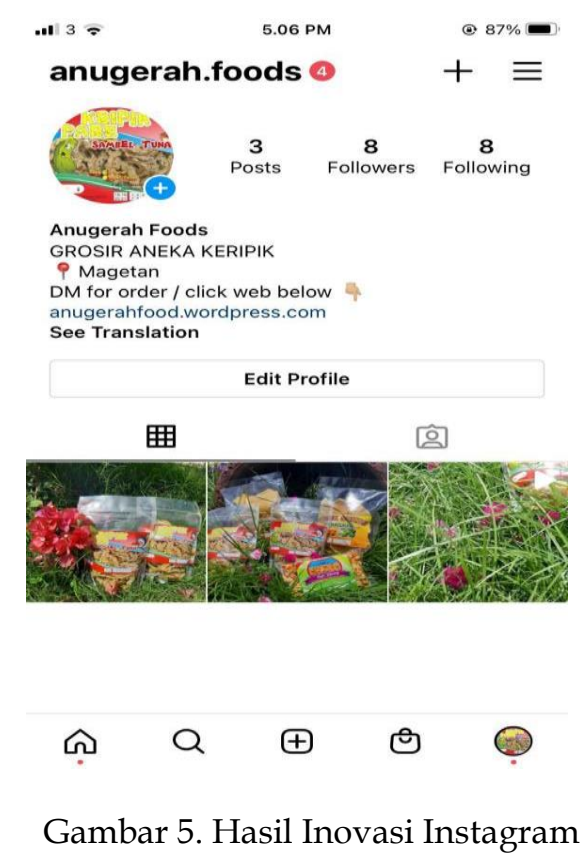

Dengan bantuan Instagram produk dari Anugerah Foods dapat membangun karakter bisnisnya. Sehingga, bisnis tersebut bisa menyasar target pasarnya. Dengan menggunakan fitur stories untuk memperlihatkan keripik pare, keripik sukun dan kacang. Dari stories itu, followers jadi tahu apa saja produk yang baru dirilis. Dengan begitu, nantinya akan banyak orang yang kemudian tahu tentang produk yang dibuat highlight melalui stories dan akan punya kesempatan untuk mendapatkan pelanggan yang baru. Begitu pula untuk cara menjalankan akun Facebook. Kurang lebih sama dengan fitur-fitur dari Instagram. Hanya berbeda platform aplikasinya saja.

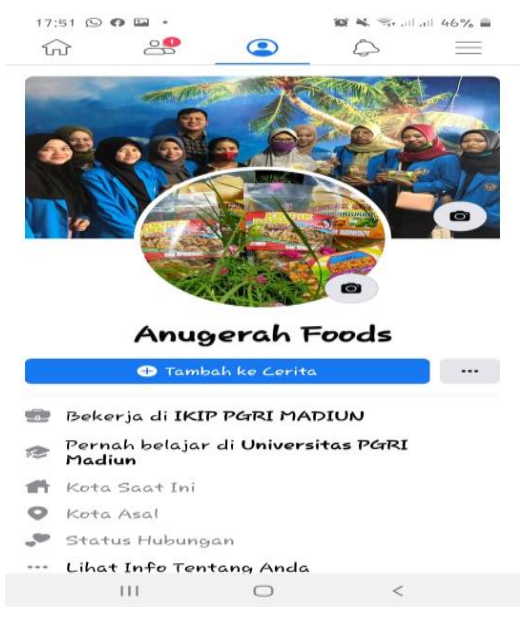

Gambar 6. Hasil Inovasi Facebook 
Dengan menggunakan Instagram dan Facebook memungkinkan untuk menjangkau banyak orang dari luar karisidenan Magetan bisa menjangkau seluruh Indonesia maupun luar negeri. internet yang lebih cepat membuat WiFi menjadi suatu hal yang penting di kalangan masyarakat modern (Fauzi. 2017)

Tentu saja, hal itu bisa terjadi karena aplikasi ini digunakan oleh orang-orang di berbagai daerah di Indonesia. Instagram memiliki fitur tab explore khusus untuk toko online. Dengan fitur ini, produk Anugerah Foods memiliki jangkuan yang lebih besar ke para penggunanya, sehingga produk Anugerah Foods akan berkembang dan dapat menarik konsumen dari berbagai daerah.

Program pengabdian masyarakat ini dapat berjalan dengan lancar. Hal ini disebabkan adanya faktor yang mendukung berjalannya program pengabdian masyarakat. Hal-hal yang mendukung berjalannya program pengabdian ini dapat diidentifikasi diantaranya antusiasme para mahasiswa dan wakil UMKM. Faktor yang mendukung program adalah antusiasme UMKM untuk memahami konsep pengembangan produk, arti strategi pemasaran dan arti penting peningkatan kualitas serta kuantitas produk. Antusisme dibuktikan dengan keaktifan UMKM dalam memunculkan inovasi berupa strategi pemasaran online pada website dan akun media sosial.

Lancarnya pelaksanaan program pengabdian masyrakat bukan berari tanpa hambatan. Selama program pengabdian ada beberapa hal yang diidentifikasi sebagai faktor penghambat kegiatan diantaranya lokasi UMKM yang berada jauh dari pusat kota dan masih minimnya fasilitas percetakan label dan kemasan di daerah tersebut.

Program pengabdian masyarakat ini mampu memberikan manfaat bagi berbagai pihak, beberapa diantaranya adalah :

1. Bagi Pengajar / Dosen

Program pengabdian masyarakat sebagai program yang dilakukan oleh dosen untuk mengaplikasikan konsep dan teori dari ilmu penetahuan yang telah di sampaikan oleh dosen di kelas. Perguruan tinggi pun turut berperan terhadap lingkungan masyarakat khususnya UMKM.

2. Bagi mahasiswa

Program pengabdian masyarakat menjadi sebuah wadah pembelajaran yang nyata bagi mahasiswa. Kegiatan ini menjadikan mahasiswa mampu mengeluarkan kreatifitas dan inovasi tentang keahlian berwirausaha, menambah pengalaman dan pengaplikasian teori.

\section{Bagi UMKM}

Dengan adanya program pengabdian masyarakat diharapkan UMKM mampu mengembangkan usahanya dan menguji strategi hasil dari sudut pandang pihak luar. 
Selain itu UMKM dituntut untuk berfikir kritis dan obyektif atas usahanya sehingga usaha yang djalankan mampu bertahan dan selalu berkembang mengikuti perkembangan zaman.

Pemasaran adalah proses sosial dan manajemen. Individu dan kelompok dapat memperoleh apa yang mereka butuhkan dan inginkan dengan menciptakan, menyediakan, dan menukar produk yang berharga dengan pihak lain (Kotler, 1997). Pemasaran adalah kunci kesuksesan bisnis.Pemasaran harus memperhatikan kebutuhan dan tuntutan kepuasan pelanggan agar dapat memperoleh kepuasan yang memuaskan dalam persaingan bisnis saat ini, sehingga berdampak positif bagi perusahaan. Diawal proses pengabdian masyarakat, kami telah mengidentifikasi bahwa permasalahan produk Anugerah Foods terletak pada segi pemasaran yang masih konvensional, yakni menggunakan kebiasaan umum yang lazim digunakan, pembeli mendatangi langsung calon penjual secara bertatap muka dan begitu pula sebaliknya.

Dengan adanya perubahan kondisi pasar, serta perubahan zaman dan perkembangan teknologi, dalam hal ini termasuk pesatnya perkembangan teknologi internet. Kebiasaan konsumsi masyarakat juga mengalami perubahan besar, dan proses pemasaran konvensional tidak dapat lagi menjangkau pasar yang luas. Orang-orang sekarang cenderung memproses transaksi dengan cepat dan efisien tanpa meninggalkan rumah untuk mendapatkan produk atau layanan yang mereka butuhkan, dan hanya menggunakan komputer/gadget pribadi yang terhubung ke internet untuk memenuhi semua kebutuhan. Saat gaya hidup dan kebiasaan konsumsi pelanggan berubah, promosi yang ditujukan untuk pemasar dan pemilik bisnis harus mengikuti perubahan ini untuk menghindari ketertinggalan. Tentunya metode pemasaran ini dapat diterapkan dengan baik oleh para pelaku UMKM, karena mereka berharap mendapatkan bisnis dan transaksi yang lebih tinggi dari waktu ke waktu.

Strategi pemasaran (Fandy Tjptono, 2000) merupakan sistem manajemen yang dirancang untuk mempercepat penyelesaian masalah pemasaran dan membuat keputusan strategis. Pemasaran berorientasi pada bagaimana pemilik bisnis atau perusahaan memenuhi kebutuhan dan kepuasan pelanggan (Fauzi,2019).Strategi pemasaran yang dipilih untuk permasalahan produk Anugerah Foods adalah marketing online. Marketing online merupakan kegiatan pemasaran yang dilakukan dengan memanfaatkan internet media sosial. marketing online atau pemasaran online adalah proses sosial dan manjerial bagi individu maupun kelompok (Kotler, 2002). Proses tersebut mengatur individu dan kelompok tadi dalam memperoleh kebutuhan dan keinginan mereka dengan membuat, menawarkan, dan melakukan jual beli. marketing online dimasa sekarang menjadi salah satu kebutuhan pokok untuk pelaku bisnis sebagai salah satu media yang paling inovatif untuk mempromosikan produk dan layanan mereka ke kalayak ramai.

Sehingga dari hasil pengabdian masyarakat ini, perubahan sosial yang diharapkan yakni kemampuan pelaku UMKM khususnya Anugerah Foods dalam memasarkan produk dapat beralih ke strategi baru, maka kami membantu permasalahan dengan pemanfaatan Instagram, Facebook dan WordPress sebagai strategi peningkatan pemasaran dan penjualan produk. Instagram adalah aplikasi berbagi foto dan video yang 
memungkinkan pengguna mengambil foto, merekam video, menerapkan filter digital, dan aktivitas jaringan lainnya (id.wikipedia.org). Facebook merupakan situs jejaring sosial yang memungkinkan pengguna berinteraksi dengan pengguna lain di seluruh dunia (Eventkampus.com). WordPress adalah aplikasi open source yang sangat populer sebagai mesin blog (id.wikipedia.org). Strategi pemasaran online diharapkan dapat membantu pertumbuhan perusahaan, membangun reputasi dan citra produk, meningkatkan brand, membidik pangsa pasar yang tepat, memastikan perusahaan memaksimalkan sumber daya yang dimiliki.

\section{E. Kesimpulan}

Program pengabdian masyarakat yang sudah dilakukan meliputi pemberian ide dan inovasi berupa marketing online dengan hasil pembuatan website WordPress dan pembuatan akun media sosial berupa Instagram dan Facebook sehingga diharapkan mampu membantu dalam proses strategi pemasaran yang dapat memperluas pangsa pasar produk. Pembelajaran bersama anggota kelompok UMKM diharapkan mampu memperbaiki usaha agar lebih baik dan maju serta mendapat keuntungan yang optimal. Program pengabdian ini juga diharapkan dapat menambah jumlah konsumen dari sentra keripik "Anugrah Foods" sehingga permintaan pasar dapat stabil ataupun meningkat dikemudian hari. Diupayakan pengembangan produk ini dapat berjalan hingga nanti agar bisnis ini mampu menciptakan produk yang lebih banyak lagi serta dapat memberikan kesejahteraan bagi anggota kelompok UMKM di Desa Jungke, Kecamatan Karas, Kabupaten Magetan.

Untuk rencana tindak lanjut, kami berharap ide dan inovasi dari kami terus dikembangkan dan aktif dilakukan di media sosial. Kami juga berharap dengan adanya ide dan inovasi ini akan memberikan penambahan penjualan dan perluasan pangsa pasar.

\section{Ucapan Terimakasih}

Alhamdulillah puji syukur kepada Allah SWT, karena kehendak dan ridhaNya kami dapat menyelesaikan jurnal ini. Penulis menyadari jurnal ini tidak akan selesai tanpa doa, dukungan dan dorongan dari berbagai pihak. Adapun dalam kesempatan ini peneliti ingin mengucapkan banyak terima kasih kepada:

1. Ibu Suparti, selaku owner Anugerah Foods

2. Isabela Indah Puspita Ningrum, Arti Cipta Nanesa, Pascawati Ida Marisa mahasiswa yang telah membantu pelaksanaan kegiatan abdimas di sentral kripik anugerah food

3. Semua pihak yang tidak dapat disebutkan satu persatu, terima kasih atas kontribusinya. 


\section{Daftar Pustaka}

Arman Hj. A , R. U. A. Fauzi , A. S. A. Ditta , I. Idris, dan M. F. M. Yazi "The Role of Perceived Benefits and Perceived Risks Towards the Consumers' Purchase Intention Via ECommerce: An Evidence From Indonesia".Solid State Technology,Volume 63 no 2s (2020)

Fandy, Tjiptono, Manajemen Jasa, Edisi Kedua.( Andy offset, Yogyakarta 2000.)

Fauzi,R.U.A, D. C. A. Kadi, R. C. Utomo, L. Dewi, dan S. R. Muhtar," Branding dan Product Inovation Pada Usaha Mikro Kecil Menengah Krupuk Bawang Desa Mrahu, :Kartoharjo Magetan." Madaniya. Vol. 1, No. 1.(2020)

Fauzi, R.U.A :The Role Of Free Wireless Fidelity (Wi-Fi) Service, Food Quality, And Servicescape Toward Customer Satisfaction." Asian journal of social science research volume 2, issue 2 ( 2019)

Fauzi, R.U.A" Marketing Strategy Analysis and Product Innovation Making added Value Bitter Melon,"Jurnal Keuangan Dan Bisnis , vol. 18, no. 1, pp. 107-115, 2020.

Fauzi, R.U.A"The Influence of Business Plan Competition and Loan Provision on Nurturing the Spirit of Entrepreneurship Among Students",Advances in Economics, Business and Management Research, volume 161, Proceedings of the Conference on International Issues in Business and Economics Research (CIIBER 2019) pp.18-192,(2021) .https:/ / dx.doi.org/10.2991/aebmr.k.210121.028

Fauzi, R.U.A."Pengaruh Harga Dan Free Wi- Fi Terhadap Keputusan Pembelian Produk Pada Angkringan Di Kecamatan Karas Kabupaten Magetan,"Jurnal Aplikasi Bisnis, vol.17 No.2, pp. 62-74, ( 2017)

Fauzi, R.U.A D. C. Ari. Kadi , G. K. S. Ernanda, P. Triwidya, and S. Adhelia,"Keefektifan Peran Digital Marketing Melalui Media Sosial Dalam Proses Pemasaran Produk Galeri UMKM Ekawira, Kare Madiun," Indonesia Berdaya, vol. 2 no. 1, pp. $21-30,(2021)$

Kadi, D. C. A., R. U. A. Fauzi, dan B. B. Cahyani “Strategi Pemasaran World of Mouth dan Online Dalam Sentra Industri Rumah Abon Ikan Lele di Jiwan Kabupaten Madiun". Journal of Social Responsibility Projects by Higher Education Forum 1(2) 49-52 (2020)

Kotler, Philip," Manajemen Pemasaran." Jilid 1.( Jakarta : Pearson Education Asia Pte, LTD, dan PT. Prenhallindo. 2002.) 
Kotler, Philip, "Manajemen Jilid 2", (Jakarta, Erlangga,1997)

Rudjito."Strategi Pengembangan Umkm Berbasis Strategi Bisnis", Makalah Yang Di Sampaikan Pada Seminar Peran Perbankan Dalam Memperkokoh Ketahanan Nasional Kerjasama Lemhanas RI Dengan BRI( 2003.)

Stanton, William J. "Fundamentals of marketing",( London, McGraw-Hill,1984.)

\section{Artikel Daring:}

Liputan6.com, Berapa Jumlah UMKM di Indonesia? Ini Hitungannya, Jumlah UMKM di Indonesia, 4 September 2020, 07.00 (diakses 5 Desember 2020), tersedia dari https://www.liputan6.com/bisnis/read/4346352/berapa-jumlah-umkm-di-indonesiaini-hitungannya

Id.wikipedia.org, Instagram, Pengertian Instagram, 23 Oktober 2020, 01.36 (diakses 6 Desember 2020) tersedia dari https://id.wikipedia.org/wiki/Instagram Eventkampus.com, Pengertian Facebook, Pengertian Facebook, 6 Juli 2018, 09.23 (diakses 6 Desember 2020) tersedia dari https://eventkampus.com/blog/detail/1401/pengertianfaceboook

Id.wikipedia.org, WordPress, Pengertian WordPress, 1 Juli 2020, 16.26 (diakses 6 Desember 2020) tersedia dari https://id.wikipedia.org/wiki/WordPress 
